
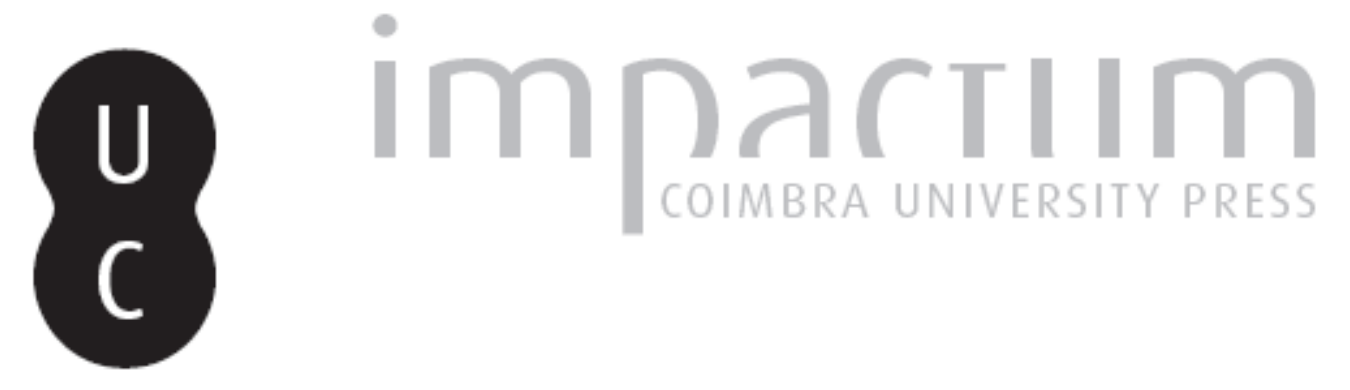

O templo e o mundo: notas sobre o lugar simbólico da poesia no século XIX

Autor(es): Santana, Maria Helena

Publicado por: Imprensa da Universidade de Coimbra

URL persistente:

URI:http://hdl.handle.net/10316.2/43717

DOI:

DOI:https://doi.org/10.14195/2183-8925_24_4

Accessed : $\quad$ 26-Apr-2023 13:33:21

A navegação consulta e descarregamento dos títulos inseridos nas Bibliotecas Digitais UC Digitalis, UC Pombalina e UC Impactum, pressupõem a aceitação plena e sem reservas dos Termos e Condições de Uso destas Bibliotecas Digitais, disponíveis em https://digitalis.uc.pt/pt-pt/termos.

Conforme exposto nos referidos Termos e Condições de Uso, o descarregamento de títulos de acesso restrito requer uma licença válida de autorização devendo o utilizador aceder ao(s) documento(s) a partir de um endereço de IP da instituição detentora da supramencionada licença.

Ao utilizador é apenas permitido o descarregamento para uso pessoal, pelo que o emprego do(s) título(s) descarregado(s) para outro fim, designadamente comercial, carece de autorização do respetivo autor ou editor da obra.

Na medida em que todas as obras da UC Digitalis se encontram protegidas pelo Código do Direito de Autor e Direitos Conexos e demais legislação aplicável, toda a cópia, parcial ou total, deste documento, nos casos em que é legalmente admitida, deverá conter ou fazer-se acompanhar por este aviso. 

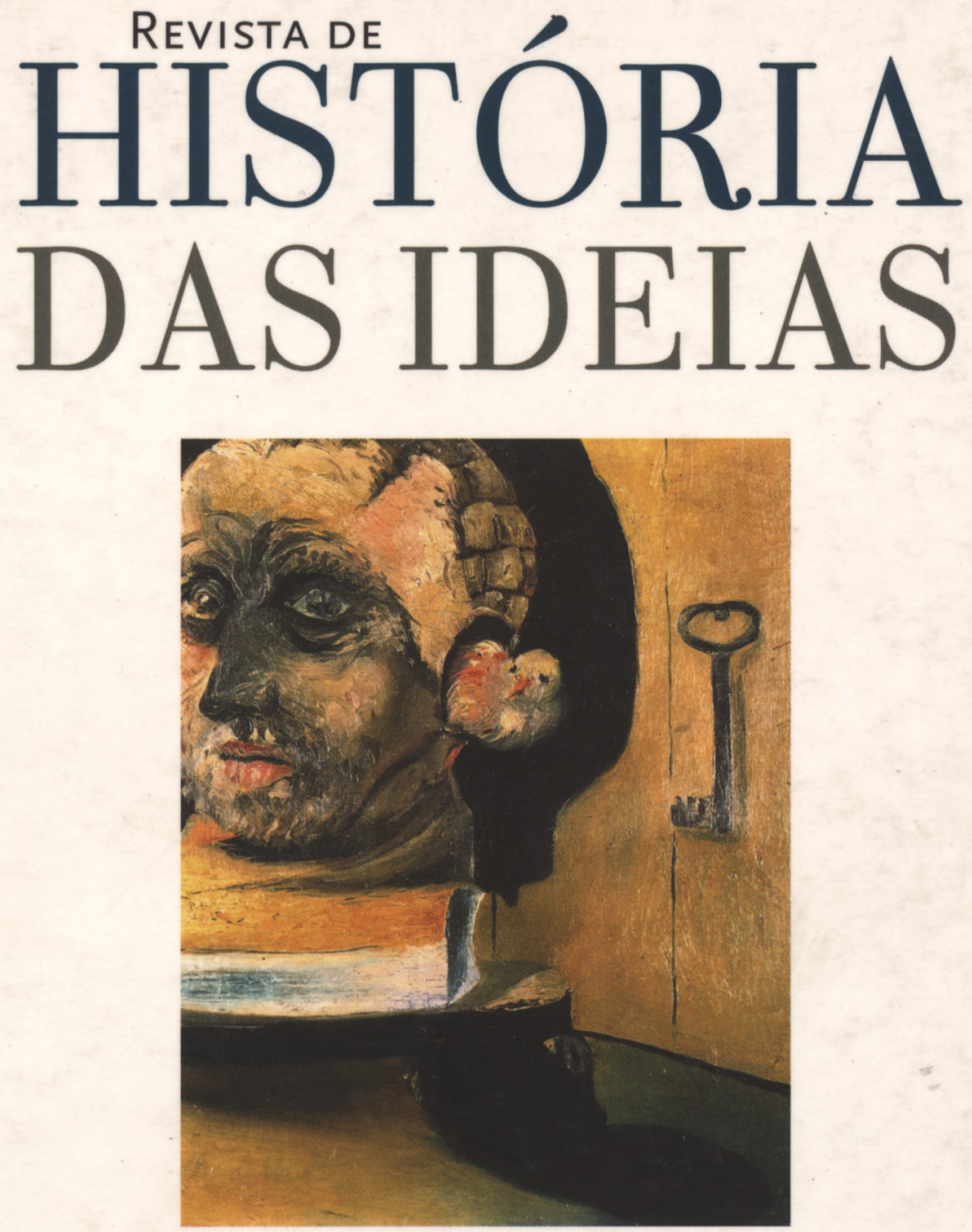

OS INTELECTUAIS E OS PODERES

Volume 24, 2003

INSTITUTO DE HISTÓRIA E TEORIA DAS IDEIAS

Faculdade de Letras da Universidade de Coimbra 


\section{O TEMPLO E O MUNDO Notas sobre o Lugar Simbólico da Poesia no Século XIX}

"Ele era homem. E homem que fazia politica, fazia livros, sistemas, eloquência, versos - isto é, mercadejava em palavras. Traficava dessa mercancia falsa e vã que não tem lei nem peso, que vem à pena ou aos lábios a contrabando d'alma e sem despacho do coração. [...] Embriagava-se nas quimeras da popularidade, nas excitações febris da tribuna, e sonhava delícias de ouro e púrpura com $o$ filtro delicioso que bebia a longos tragos no aplauso das multidões".

Almeida Garrett, "A Cruz", ms. inédito

"Fazei o tabalhador da pena, independente, desamarrado dos interesses e dos afectos, apto a ver d'alto a vida e os seus assuntos: que só assim cabeças fortes podem gerar ideias sãs, e a intelectualidade logra retomar nas sociedades o seu lugar de força dirigente. E a reintegração do pensador e do escritor no papel de meneur de turbas amorfas, só nesta terra o dinheiro a poderia iniciar".

Fialho de Almeida, "Coelho Netto", in Barbear, Pentear

A primeira citação transcrita, extraída de um texto inédito de Almeida Garrett ${ }^{(1)}$, datado de 1849 , alegoriza o conflito íntimo do escritor

* Faculdade de Letras da Universidade de Coimbra.

(1) Almeida Garrett, "A Cruz", texto incompleto, variante de "A Cruz e o Perjúrio", extraído do Ms. $n^{\circ}$ 76/77 do Espólio de A.G., org. por H. Ferreira Lima, pertencente à Biblioteca Geral da Universidade de Coimbra. Agradeço à Prof. ${ }^{a}$ Ofélia Paiva Monteiro as informações acerca deste texto. 
romântico, dividido entre a sedução do mundo e os valores do coração. Contextualizando o passo, importa dizer que a personagem (o poeta) se encontra à cabeceira duma mulher moribunda, para quem o amor constituiu sempre um valor absoluto. Arrependido, o poeta faz um balanço crítico de uma vida consagrada aos prazeres do espírito (que não da alma) e à embriaguês da fama. $O$ acento coloca-se no valor de troca da palavra - a popularidade -, cuja negatividade se exprime no carácter redutor dos termos utilizados: mercancia, contrabando, traficar, mercadejar. Desconfiar do poder alienante do intelecto e da palavra é um paradoxo muito glosado pela literatura romântica, e não deve levar-se demasiado a sério. Noutros contextos, os mesmos autores não deixarão de prestar culto ao altar sagrado da palavra do poeta, mesmo se este toma por momentos a tribuna do político; a única condição é que ela não se transforme em palavra mercenária, posta ao serviço de interesses particulares ou menos dignos.

A segunda citação, de Fialho de Almeida(2), fala-nos da condição do profissional das letras no virar do século, confrontado ante a alta função social que lhe está cometida - de guia espiritual das turbas - e o fraco reconhecimento real de que usufrui. Aparentemente, o apelo ao "vil metal" (rara franqueza num escritor) poderia referir-se ao produto do livre comércio intelectual. Não é bem o caso: trata-se sobretudo de garantir a independência económica ao escritor para que ele possa exercer na sociedade o nobre estatuto de que se julga credor. Aliás, a má consciência em relação ao destino mercantil do pensamento criador permanecerá como uma das questões mais controversas para os escritores oitocentistas, quando se interrogam sobre o valor simbólico das suas produções.

Sirvam-nos estes textos de epígrafes para uma breve reflexão sobre o lugar do homem de letras, em particular do criador literário, no século que o consagrou como intérprete do tempo moderno; uma questão que inevitavelmente se articula com a função social da Poesia no quadro

(2) Fialho de Almeida, "Coelho Netto", in Barbear, Pentear (Jornal d'um vagabundo), $5^{\text {a }}$ ed., Lisboa, Livr. Clássica Editora, 1960, p. 154. Não se conhece a data exacta do artigo, que Costa Pimpão diz ser posterior a 1895; foi publicado postumamente no referido volume. $O$ brasileiro Coelho Netto serve apenas de motivação ao texto de Fialho por ser um caso raro de sobrevivência pela produção literária num escritor de língua portuguesa. 
concorrencial dos poderes e dos saberes. Observá-lo-emos através do testemunho de alguns escritores e críticos em dois momentos diferentes: na época do primeiro romantismo, quando o campo literário nacional dava os primeiros passos no sentido de afirmar a sua autonomia; e na época positivista, em que o lugar social da Literatura está já bem definido, em moldes sensivelmente idênticos aos dos nossos dias.

1. Um dos desideratos da revolução liberal foi o alargamento das luzes às classes médias $\mathrm{e}$ ao povo, com vista à criação de um espaço cultural participado e tanto quanto possível emancipado dos poderes instituídos. Chamados à ribalta política pela própria ideologia civilizadora da revolução, os intelectuais, homens de letras na sua maioria, tiveram uma ocasião única de exercer um papel de liderança na vida pública, chamando a si a missão de educar a nação e de regenerar as instuituições. Esta é também uma das razões que explicam o compromisso do nosso primeiro romantismo com a História, acolhendo a ideia de uma literatura actuante e portadora de valores sociais.

Não iremos aqui reconstituir as várias facetas que marcaram o combate da intelligentsia liberal no sentido de criar um terreno propício ao florescimento das artes e das ciências, numa sociedade mal preparada para usufruir dos bens culturais. Sublinhemos apenas que os esforços empreendidos nesse combate, porquanto meritórios, não foram inteiramente desinteressados. Como amplamente demonstrou Maria de Lourdes Lima dos Santos, num estudo de referência ${ }^{(3)}$, o empenhamento dos intelectuais vintistas na arena pública não escondia as suas aspirações a um papel social e político que consideravam ser-lhes devido; reclamavam-no em função de uma ideia emancipadora da cultura que, no mesmo impulso em que se "democratizava", a si mesma se sublimava.

Ninguém melhor do que o autor de Portugal na Balança da Europa - que em si próprio reuniu o estatuto privilegiado de poeta-soldado, político militante, homem de letras e homem do mundo - para ilustrar, através dos seus textos de intervenção, algumas das ideias que nortearam a campanha liberal em favor da cidadania cultural. Note-se que, apesar de Garrett promover a figura poeta-cidadão, o lugar específico que lhe

(3) M. de Lourdes Costa Lima dos Santos, Intelectuais Portugueses na primeira metade de Oitocentos, Lisboa, Presença, 1988. 
atribui nem sempre fica muito claro nestes textos, como de resto não o era no quadro conceptual da época. Coexistem, na primeira metade do século, um conceito iluminista da cultura que não valoriza hierarquias ou divisões no saber e um conceito romântico que vê o escritor literário, bafejado pelas musas, como portador de um verbo e de um visionarismo excepcionais; um estatuto que lhe reserva um lugar destacado, mas ao mesmo tempo marginal na sociedade do tempo. Embora adoptassem, segundo as situações, o perfil que mais lhes convinha, os nossos escritores reclamaram-se de forma mais consistente do estatuto de homem de letras, aquele que lhes proporcionava um espaço de intervenção mais amplo e mais legitimado.

Começaremos por nos referir à Carta de Guia para Eleitores, redigida em 1826, pelo então oficial da Secretaria de Estado dos Negócios do Reino(4). Tendo-lhe sido pedido um parecer sobre os critérios de escolha dos deputados, Almeida Garrett produz uma pioneira reflexão sobre o perfil social e intelectual das classes dirigentes, num país que dá os primeiros passos na governação moderna e democrática. O elemento mais interessante a destacar do texto é decerto a defesa da opinião pública como principal autoridade ("máxima e talvez única") no processo de selecção. Garrett chama-lhe rainha tutelar do mundo, sublinhando assim a importância conferida à soberania da palavra no novo espaço político. Não se pense, porém, que soberania se confunde com democracia, no sentido actual do termo: para que a opinião pública não desvirtue a sua função, necessário se torna, segundo o escritor, que ela nasça do espírito público, filho por seu turno do interesse comum, que se gera no seio duma sociedade livre e ilustrada. De resto, nunca os intelectuais vintistas sustentaram a ideia de uma democracia directamente entregue ao impulso popular, sem a mediação de uma classe dirigente esclarecida e culta, que lhe servisse de guia e de intérprete.

Incompatível com o espírito de partido, o espírito público define-se então como "a parte mais ou menos activa que toma a porção ilustrada da população no sistema geral de seu governo, e nos actos particulares de sua administração". Ao subscrever esta fórmula, Garrett deixa claro

(4) Almeida Garrett, Obras, vol. I, Porto, Lello \& Irmão Editores, 1963, pp. 1077-1086. Para uniformizar as referências, todas as citações remeterão para esta edição, indicando-se apenas o volume e a página. 
o princípio segundo o qual as luzes do saber ("a ilustração") oferecem garantia de entendimento do que possa ser o interesse colectivo, bem como das várias armadilhas que o pervertem: "Nada pode haver comum entre este espírito filho da ilustração, e a estupidez da massa ignorante tão inábil para conceituar de um princípio, como para lhe calcular ou observar as consequências"(5).

Postas as considerações gerais, a questão seguinte diz respeito ao discernimento da dita opinão pública, quando estão em causa os "mais notáveis" dos cidadãos ilustres. Além da isenção partidária e da ilustração, exigem-se-lhe, para um juízo esclarecido, qualidades de imparcialidade e moderação; e exige-se consenso e factos. Por outras palavras, um homem tem a seu favor a "opinião" quando, sem exageros e sem oposição, dele se pode afirmar que tem saber, desempenho ou virtudes distintas; não por simpatia ideológica, mas porque os seus actos ou os seus escritos o comprovam. A liberdade de imprensa - tema a que, poucos anos antes, Garrett consagrara um poema ${ }^{(6)}$ - assume neste ponto um papel de inquestionável importância, como condição de existência da razão crítica.

Finalmente (e deixando de lado a parte propriamente política do texto), o autor estabelece os mandamentos do bom deputado: amor da causa pública, amor da liberdade, honra, probidade, moderação, religião (sem fanatismo), saber, exercício de uma profissão, rendimentos mínimos, etc. De todas as prescrições, as que se referem ao saber sobressaem pelo pormenor das especificações: letras mas sem tretas, ou seja, não se quer conhecimento "de estrangeirices e modernices afectadas" nem "sabichões que sabem só dos seus livros", nem "casquilhices de ciência pedante"; quer-se, sim, "saber provado por escritos, por desempenho de funções, e não pelo dito de meia dúzia de amigos que exclamam na sua roda: forte homem!".

Para além do pitoresco, deve observar-se a preocupação do jovem Garrett em salvaguardar a dignidade do saber -e das Letras em particular - em função da sua utilidade e reconhecimento efectivos. É homem de letras aquele que tem obra feita e que não se subtrai à prova do juízo

(5) Ibidem, p. 1078.

(6) Trata-se do poema XI da Lírica de João Mínimo, "A liberdade da imprensa", datado de 1821, onde se reclama em tom épico a ansiada luz da Verdade, acompanhada das suas filhas foragidas, a Razão e a Justiça. 
público. Como se vê, o escritor não fala em nome de um saber ou de um estatuto específicos, mas na ampla acepção do intelectual criado pelas Luzes, que lhe reserva o privilégio de exercer na esfera pública o seu magistério político, moral ou social. Não se esclarece, por ora, se tal estatuto constitui uma profissão ou simplesmente uma mais-valia de distinção social; no entanto o escritor teria outras ocasiões de o explicitar.

A "antiga e bela utopia da universal república das letras", de matriz iluminista, é também a ideia inspiradora do projecto de lei sobre a propriedade literária e artística, apresentado por Garrett à Câmara dos Deputados, em $1838^{(7)}$. "Prestámos homenagem à força intelectual, ao poder do espírito" - afirma-se, no início do texto - por consagrar tal matéria no direito constitucional. Que não se entenda como um privilégio, mas antes como a legitimação de um bem que só existe na medida em que a sociedade o recebe e reconhece, eis o que o autor reiteradamente argumenta, apoiando-se no espírito democrático do século. Nesse sentido, a nova lei pretende fomentar a livre comunicação do saber e do pensamento e abolir as feudais "alfândegas do espírito" que perpetuam as tradições do despotismo. Ora, continua Garrett, se o espírito cria o pensamento isoladamente, a glória nasce com a comunicação, o que implica a concorrência da sociedade. Ambas têm direitos a salvaguardar. Em lugar do favor discricionário de Mecenas, o talento deverá ser protegido por leis, mas o seu verdadeiro regulador será sempre o tribunal, ainda que falível, da opinião pública, estribada na liberdade de imprensa: "Ojuízo público, a opinião não comprável protegerá ao mérito desvalido e tímido, e despirá das penas do pavão a gralha soberba e confiada"(8).

O contrato com a sociedade, garantindo-lhe direitos, não isenta o intelectual de obrigações, quer perante o país e o povo que os acolhe, quer perante a república literária una e indivisivel, que não conhece fronteiras nem soberanias. Promover essa unidade, não a traindo com divisões de cariz político ou religioso, é a primeira obrigação dos homens de letras. Isso mesmo pode ler-se no parecer sobre "Neutralidade política em Literatura", emitido, em 27 de Agosto de 1846, por uma comissão encabeçada pelo autor de Frei Luís de Sousa: "Seja a profissão e os professores das letras sagrados para os partidos, e não lhes paguem tributo como os descendentes de Harmódio e Aristogíton entre os atenienses o não

\footnotetext{
(7) Obras, I, p. 1210 ss.

(8) Ibidem, p. 1216.
} 
pagavam à república"(9). O parecer destinava-se a salvaguardar a livre colaboração dos escritores e outros intelectuais em publicações, ou instituições de qualquer tendência política, sem que isso os comprometesse partidariamente; sugeria inclusivamente uma lei que, dentro do mesmo espírito, considerasse inamovível todo o emprego ou cargo literário em caso de discordância ideológica.

Uma segunda obrigação, seguindo ainda o pensamento de Garrett, consiste no dever de consciência de, enquanto literato, manter a independência do espírito (e das obras) face aos poderes políticos e sociais. Se a prática de tão nobre princípio se afigurava à partida complicada, dadas as várias facetas do homem público que também era, o escrúpulo deve contudo registar-se. A polémica gerada em torno da publicação d'O Arco de Sant'Ana, em 1845, deu-lhe oportunidade de o demonstrar: ao afrontar directamente a instituição clerical e o governo cabralista, o autor foi acusado de ter escrito um "romance de oposição", ousadia que lhe trouxe alguns dissabores. Quer em público quer em privado, o escritor afirma não fazer corte a nenhum poder, princípio que integra na sua retórica parlamentar: se bem que não deixe de invocar o seu currículo político invejável e os serviços prestados à causa da revolução, é como pobre homem de letras, isto é, cidadão independente e livre, que prefere situar-se entre os colegas deputados ${ }^{(10)}$. Também em cartas privadas por diversas vezes declara não prostituir os seus versos nem ter o nocivo hábito de celebrar méritos de gente viva: constrange-o o perigo da lisonja e até mesmo, como confessa, a presunção de que o não tratassem de poeta, no sentido vulgar do termo ${ }^{(11)}$.

(9) Obras, I, pp. 610-611. O parecer foi seguido de uma declaração solene, assinada por Garrett, Herculano, Rodrigo da Fonseca Magalhães e pelo Visconde de Juromenha, invocando a independência do "mister das letras, das ciências e das artes" face às questões governativas e partidárias e o direito a exercê-lo livremente, em qualquer órgão, sem quebra das convicções próprias. Unia-os, segundo o textos, o espírito de tolerância cristã e o supremo intuito de contribuir para o aperfeiçoamento da civilização intelectual e moral (p. 612).

(10) "Bem sei que para mim não há, não pode haver, nem o favor dos palácios, nem a aura dos comícios. [...] O único estado e profissão que tenho e prezo, nem de uns nem de outros depende; e a ambição que ainda pode algum tanto comigo, não são eles que a satisfazem. O pobre homem de letras tem ao menos esta vantagem": Discurso parlamentar de 12.10.1837, Obras, I, p. 1262.

${ }^{(11)}$ Cf. carta a Pedro A. Borges, de 22.2.1845, Obras, I, pp. 1433-1435. 
Garrett sempre evitou, com efeito, apresentar-se no espaço público com o rótulo de poeta, que se revestia de conotações embaraçosas e pouco compatíveis com a sua concepção mundana do escritor moderno. Associava provavelmente o termo ao "vate" dos tempos passados, marginalizado e sofredor; tão-pouco se identificava (a não ser como tema ou cliché literário) com o seu avatar romântico, o profeta visionário que só condescende em descer ao mundo dos homens para lhes revelar as grandes verdades espirituais.

A visão mitificada do poeta agradava porém ao perfil austero de Herculano, o que não surpreende no cultivador de um ideal ascético e quase cenobita do homem de letras. Para o autor da Voz do Profeta, a poesia é um eco das harmonias celestiais e o poeta uma voz investida duma aura quase divina que tem o poder de inspirar ao coração humano o sentido transcendente das virtudes intemporais:

“O poeta, como o artífice ou o filósofo, é levado pelas opiniões e costumes do século; porém no âmago dos seus cantos há sempre um ou muitos pensamentos perpétuos e imutáveis. [...] São eles os depositários de uma herança de virtude: e desgraçado daquele que falsando a sua missão na Terra, conspurcou com o lodo das paixões ignóbeis o tesouro do génio humano.

O génio, pois, é superior a esse progresso lento de cálculos e raciocínios, a esse aumento de complicação na máquina social, a que se chama aperfeiçoamento. Como um deus ele grita à imaginação do povo: crede-me porque sou omnipotente - e o povo levanta um clamor de admiração, e diz ao génio: 'Tu és, com efeito, um deus'"(12).

Assim entendida, a poesia que se desvia dos sublimes sentimentos universais - o amor da virtude, o amor da pátria - só pode constituir uma espécie de traficância mundana, e o versejador que a pratica, mesmo o mais hábil, não passa de um "menestrel parasito". A expresssão é significativa, na medida em que traduz o fraco conceito que Herculano tinha do emergente "profissional das letras", sujeito às pressões da popularidade e aos interesses mesquinhos do vulgo e, por extensão, a sua

(12) "Poesia" (texto publicado n'O Panorama, em 1837), in A. Herculano, Opúsculos, vol. V, org. de Jorge Custódio e José M. Garcia, Lisboa, Presença, 1986, pp. 135-137. 
reserva em relação de todas as formas de trivilização da escrita, como o moderno folhetim.

Como podia pois Garrett rever-se naquele estatuto transcendente, sendo ele um homem dos salões, dos jornais e do teatro, um escritor ecléctico que não desdenhava cultivar, ao lado dos géneros literários nobres, a literatura de sociabilidade, como o romance-folhetim e a revista feminina? Como poderia o autor d'As Viagens e d'O Toucador representar-se sem desconforto na figura profética do poeta, quando a sua própria experiência social lhe indicava ser outro o sentido da modernidade?

Se é verdade que no prefácio a Folhas Caídas o vemos resguardar a voz poética no olímpio etéreo do "espírito", a quem o mundo não tem que pedir contas ${ }^{(13)}$, deve também assinalar-se o facto de bem cedo (no texto que serve de introdução à Lírica de João Mínimo, de 1828) Garret ter compreendido o quão obsoleto e fragilizante esse lugar se tornava no devir mais alargado da palavra e do saber modernos: "[...] porque hoje a moda é prosa e mais prosa, economias políticas, estatísticas, químicas, físicas, e outras inúteis frandolagens que nunca entraram nas topetadas e apolvilhadas cabeças de nossos pais..."(14). Neste prefácio, a vários títulos interessante, o pseudo-editor dos poemas explica como João Mínimo podia facilmente passar despercebido numa época em que a vil prosa do romancista faz já esquecer a antiga poesia: "Que é dos poetas portugueses de hoje? Que se não pode chamar poetas a esses fazedores de poemas e romances - enfronhados em românticos, - ou a esses frios imitadores de Horácio no género lírico, que fazem odes com senso comum $[\ldots . .]^{\prime \prime(15)}$.

O biógrafo de J. M. antevê tempos difíceis para os poetas que não souberem adaptar-se às novas realidades do campo literário: a poesia declinava porque acabavam também os espaços electivos da sociabilidade setecentista, ou seja, porque o jornal substituía os outeiros e os salões aristocráticos; porque o poder absorvente das "endiabradas políticas" e do racionalismo tudo pervertem, transmitindo-se à própria essência

(13) "Deixai-o passar, porque ele vai onde vós não ides; vai, ainda que zombeis dele, que o calunieis, que o assassineis. Vai, porque é espírito, e vós sois matéria", Folhas Caídas, "Advertência" (1853), ed. cit., vol. II, p. 158.

${ }^{(14)}$ Cf. "Notícia do Autor desta Obra", Lírica de João Mínimo, ed. cit., vol. I, pp. 1483-1499 (citação na p. 1484).

(15) Ibidem, p. 1485. 
da linguagem literária ${ }^{(16)}$. A nostalgia com que evoca esses bons velhos tempos só pode exprimir-se com distanciada ironia, tanto mais que acaba de fazer a reportagem dum outeiro, já então um evento pitoresco e anacrónico. De resto, a ironia torna o biógrafo cúmplice do verdadeiro autor do texto, cujas "modernices" românticas se afastam do ideal remoto aqui representado por João Mínimo, poeta-sacristão.

O que Garrett soube também perceber (talvez com alguma inocência) foi que a emancipação do talento artístico, corolário duma sociedade civilizada e liberal, implicava como contrapartida a aceitação de uma nova instância reguladora - o mercado - e do poder acrescentado da Crítica, nascida da famosa opinião pública. Respondendo, embora tardiamente (em 1851), ao projecto de lei sobre a propriedade literária, Herculano, fiel ao seu idealismo poético, expõe as razões da discordância. Repugnava-lhe desde logo a ideia de propriedade sobre um bem que por essência considerava universal, e repugnava-lhe mais ainda que um produto de natureza espiritual, emanação do Verbo divino, pudesse ser objecto de um mecanismo de compensação simplesmente monetária:

“O que me parece inelutável, sr. visconde [...] é que o escritor, ao mesmo tempo homem de trabalho e evangelizador da civilização e do progresso, exerce na terra um duplicado mister. Na feitura de um livro há dois fenómenos distintos: um material, outro imaterial. [...] Se a imprensa é um sacerdócio, não confundamos o que há nela elevado e espiritual com o trabalho venal e externo; não instituamos a simonia como um direito $[\ldots]^{\prime \prime(17)}$.

Os argumentos utilizados não deixam de ter coerência, dum ponto de vista teórico. Se o valor do pensamento não se afere por "capital produtivo" mas antes "moral", a digna retribuição do escritor estaria na

(16) "As endiabradas políticas tudo absorvem. E eles, os romancistas, os nacionalistas, os racionalistas, os inimigos da brilhante antítese, do campanudo conceito, da fina e intrincada e ininteligível frase sublime... eles ganham terreno; e talvez, talvez não tarde a época [...] em que as éclogas de João Xavier, e de muitos outros, causem sono, os sonetos elmanísticos fastio, e as epopeias agostinhas nojo" (p. 1486).

(17) A. Herculano, "Da propriedade literária e da recente convenção com a França - ao Visconde d'Almeida Garrett (1851)", in Opúsculos, vol. I, ed. cit., 1982, p. 227 ss. 
glória intelectual, na consideração social, em "sentir-se grande"; estaria, em suma, na opinião pública, o lugar virtual onde efectivamente existe. Um sistema complementar de recompensas (cargos, prémios, etc.) por parte de Estado poderia proteger os neófitos e servir de estímulo à criação; ao mesmo tempo preveniria a anarquia que resulta do que chama o industrialismo literário, fenómeno já então emergente entre nós, pela importação dos romancistas da moda, os Balzacs e os Kocks. Ao acusar o colega de ligeireza, Herculano lembrava-lhe, portanto, que o triunfo dos barões em breve penetraria o templo literário sob a forma da produção de consumo, ou "literatura-agiotagem", como prefere designá-la.

$\mathrm{Na}$ altura da aprovação da lei (em 1841), Garrett não tinha decerto razões para temer os perigos do dito industrialismo; pouco depois ele próprio ironiza sobre o tema, n'as Viagens, explicando ao leitor como se constroem dramas e romances em série. Além do mais, todo o seu percurso o inclinava a defender sem reservas o princípio liberal. O ponto culminante desta retórica encontra-se na conhecida passagem da Memória ao Conservatório Real:

"Este é um século democrático; tudo o que se fizer há-de ser pelo povo e com o povo... ou não se faz. Os príncipes deixaram de ser, nem podem ser, Augustos. Os poetas fizeram-se cidadãos, tomaram parte na coisa pública como sua; querem ir, como Eurípides e Sófocles, solicitar na praça os sufrágios populares, não como Horácio e Virgílio, cortejar no paço as simpatias dos reais corações".

Até meados do século o ideal de democraticidade, fortemente apelativo, dominou o discurso relativo à autonomia do campo literário. Um sinal disso mesmo foi a reacção de alguns intelectuais ao papel da Academia como órgão privilegiado de consagração. Garrett não quis ou não se atreveu a questionar a veneranda instituição, que só tardiamente o acolheu. Mas algumas das suas posições deram certamente argumentos ao texto contundente que Latino Coelho publicou em 1850, n'O Ateneu, sob o título "Quais são as vantagens das academias reais?"(18):

(18) Latino Coelho, "Quais são as vantagens das academias reais? ", O Ateneu, $\mathrm{n}^{\circ} 14$ e 15 , Lisboa, 1850. 


\begin{abstract}
"Houve tempo em que eu cria na academia como num manancial de progresso. Hoje descreio-a como uma irrisão, como um insulto petulante à história das letras, e ao génio. [...] As academias não criam nada, e esterilizam muito. A academia é uma aristocracia, bastarda, reflexo da ordem patrícia na vida singela e pura da ciência. Ora, quando nos insurgimos contra as oligarquias, para que havemos de ir prostrar-nos em adoração de hiperdulia diante duma nobreza sem significado?".
\end{abstract}

Nas palavras de Latino Coelho, uma Academia, como templo do saber, constitui um reduto anacrónico de uma época pré-crítica. Não é ela que derrama a sua luz sobre as letras e as ciências, mas, ao contrário, limita-se a receber o reflexo do ambiente cultural circundante. Mais: pela sua natureza impositiva, é um órgão contrário "ao código liberal da mais democrática e soberana de todas as repúblicas, a das letras". A prova é que o escritor entronizado em geral morre para as letras, enquanto o escritor de génio (o caso de Garrett) raramente vê o seu mérito reconhecido em tempo útil. No caso português, continua o autor, o florescimento da Academia foi sempre inversamente proporcional ao da cultura. Agora, que a instituição fenece, a nação progride através dos legítimos veículos do saber: a educação difundida pelo povo, a comunicação com os focos modernos do saber e da arte e, acima de tudo, pela imprensa livre. Esta é a nova instância reguladora, "parlatório de todas as inteligências", "academia democrática e universal de que todos são membros".

Se o favor institucional, sucedâneo do favor mecenático, já não se admite, qual será então a certidão e a moeda de troca do talento? A resposta adivinha-se: a glória, que se afere pelo reconhecimento das gerações vindouras, mas também a certeza de ser lido pelo povo, traduzido, citado, enfim, venerado pelas capacidades comprovadas: "Esse é o verdadeiro culto, esse o verdadeiro templo", conclui Latino Coelho.

A gerações seguintes dar-lhe-iam razão, embora recusassem confundir o sucesso comercial ou a veneração dos seus pares com a justa apreciação do seu valor. Mutatis mutandis, reencontraremos a mesma retórica de conotação política no combate dos jovens intelectuais durante a famosa Questão Coimbrã. A diferença é que a luta se travaria então não contra a Academia dos sábios, mas contra os "pontífices das Letras", ou seja, no interior do campo literário. É certo que também os primeiros românticos tiveram que impor uma estética e defender os seus méritos 
face aos "antigos"; mas o contexto revolucionário, apologista do nacionalismo e da modernidade, foi-lhes também nesse ponto favorável. O que estaria em causa em 1865 não era simplesmente uma ideia nova mas um problema novo na cena literária portuguesa: o direito dos "dissidentes" a um lugar ao sol na república das letras. Tratava-se, afinal, de pôr em prática o projecto de autonomia preparado pela primeira geração romântica.

2. A $2^{\mathrm{a}}$ metade do século, depois do fulgor passageiro da retórica humanitária, nos anos 60 e 70, remete a poesia (e o poeta) para uma esfera de comunicação cada vez mais restrita e intimista. Cesário Verde, em plena voga parnasiana, queixava-se em 1876 de não poder publicar um folhetim de versos ${ }^{(19)}$; Gomes Leal, um dos artistas mais celebrados da mesma época, acaba os seus dias na mais degradante miséria, mostrando aos seus colegas que o reinado da palavra poética continua a ser uma questão circunstancial.

A derivação para a "religião" autocontemplativa da arte, que entre nós só surgirá numa fase tardia, vem demonstrar que a promoção sacerdotal da poesia era de facto frágil e pouco reconhecida pelo público, como defende Paul Bénichou; segundo este estudioso, tratou-se sobretudo de um epifenómeno cultural - a necessidade de preservar o sagrado, laicizando-o, numa sociedade que caminhava decisivamente no sentido da positividade ${ }^{(20)}$. Os poetas finisseculares, que assistiram resignados

(19) Referimo-nos ao poema "Nevroses", depois intitulado "Contrariedades", onde se descreve de forma lapidar o funcionamento do mercado editorial, de que destacamos duas estrofes:

Receiam que o assinante ingénuo os abandone, Se forem publicar tais coisas, tais autores.

Arte? Não lhes convém, visto que os seus leitores

Deliram por Zaccone.

Um prosador qualquer desfruta fama honrosa, Obtém dinheiro, arranja a sua coterie;

E a mim, não há questão que mais me contrarie Do que escrever em prosa.

(20) "Le poète [...] avait toujours été, dans la société européenne, un personage marginal, peu apte par nature à prendre part aux affaires humaines. Sa promotion à un haut rang $[. .$. ] était née du besoin de conserver le sacré en le laïcisant. Mais cette promotion survenait dans une époque où l'intervention de Dieu dans 
ao triunfo da prosa vil, compreendem finalmente que o tempo da sua missão social acabou e procuram sublimar o desencanto refugiando-se no espaço corporativo das suas revistas e dos seus cenáculos decadentistas. Desligada do grande público e sem qualquer intenção de o endoutrinar, a poesia vive então, sem voz épica, no círculo aristocrático dos happy few.

Conscientes do seu domínio, tanto no plano literário como social, os prosadores da época positivista encarregar-se-ão de caricaturar os sobreviventes da geração romântica que não souberam adaptar-se ao espírito e às condições de existência - pragmática e burguesa - dos novos tempos. Eça de Queirós deixou-nos expressivas figurações do poeta decadente no Alencar d'Os Maias e no conto Um Poeta Lírico; ainda n'Os Maias, o episódio patético do sarau literário (situado por volta de 1875) põe em evidência, mais do que a mediocridade duma certa poesia que se quer militante, o seu completo alheamento da realidade social.

Subsistirá todavia no $3^{\circ}$ quartel do século a nostalgia do Poeta que o romantismo sacralizou, se bem que algumas das suas características sofram uma sensível mutação. Trata-se agora do poeta-filósofo, inspirado do alto mas comprometido com o destino colectivo da Humanidade. Essa figura de síntese, que em França surgiu ainda na primeira vaga romântica, epitomizada em Vítor $\mathrm{Hugo}^{(21)}$, é o poeta cujo verbo eloquente não basta para se poder erigir em mobilizador das turbas. Exige-se-lhe o vigor das ideias e a consciência, ainda que difusa, dos novos caminhos do pensamento crítico. Isto equivale a dizer que o lugar central da intelligentsia se deslocou de facto para essa outra voz ispiradora que é o filósofo-ideólogo, intérprete da História. Aos poetas pede-se que "adivinhem" o sentir da colectividade humana e propaguem pela magia da palavra o que os outros deduzem no recato das suas bibliotecas.

les affaires humaines, et la possibilité d'un sacerdoce quel qu'il fût, avaient cessé justement d'être objet d'une véritable croyance", Paul Benichou, L'Ecole du Désenchantement, Paris, Gallimard, 1992, pp. 581-582.

(21) Paul Bénichou situa o "Poète penseur" na confluência do pensamento progressista e do espiritualismo romântico, definindo-o como "un inspiré porteur de lumières modernes en même temps que de mystère, montrant aux hommes, en les accompagnant dans leur marche, un but distant et pur": Idem, Le Sacre de l'Ecrivain (1750-1830), Paris, José Corti, 1973, p. 470. 
Encontramos esta ideia exemplarmente descrita nos textos de crítica literária de Oliveira Martins, em particular nos que dedica à chamada "Escola Nova". Para o mais influente ideólogo português, os poetas podem e devem ter um importante papel "moral" (leia-se político) na sociedade; eles são "precursores inconscientes que sentem o que não lhes é dado definir - incitam, preparam, decidem o caminhar ondulado da massa de homens que progride na larga via da História"(22); mas não cabe à Poesia "formular-nos as soluções ou mesmo enunciar-nos os dados do problema social" (23). Por isso ele se permite esclarecer Junqueiro sobre a ideia que preside à sua obra e que os olhos de artista do autor, viciados em convenções literárias, não alcançam. Semelhante atitude tomará aliás o ideólogo positivista Teófilo Braga relativamente ao "artista" Eça de Queirós, por não ter sabido interpretar o sentido da sociologia positiva n'O Primo Basilio.

Deve dizer-se que, na escala de valores de Oliveira Martins, poesia e literatura, poeta e literato (ou artista) não são termos semanticamente idênticos: poeta é aquele que vê ou pressente a essência dos fenómenos ou das realidades humanas; artista aquele que sente e sabe exprimir o lado belo das coisas, fruto duma aprendizagem literária que tanto pode converter-se numa obra de sucesso como num mero exercício retórico, artificial. Assim a "alta região da poesia" é a que provém do sentimento associado à razão especulativa, e o verdadeiro vate - o caso único de Antero - será antes de mais fisósofo, por definição anacoreta ${ }^{(24)}$. Por isso mesmo a restante poesia - sentimental, parnasiana, didáctica, lírica em geral - recebe nos seus textos críticos apreciações condescendentes, quando não depreciativas: "um cordial suave", "quadrinhos", "bricabraque", words... A desconfiança em relação ao engenho artístico (sinónimo desqualificante de literatura) estende-se naturalmente à narrativa $e$ mesmo ao romance realista coevo, género que, para este crítico, parece revestir-se de alguma frivolidade.

(22) "A poesia revolucionária e a A Morte de D. João" (1874), in Oliveira Martins, Literatura e Filosofia, Lisboa, Guimarães Editores, 1955, p. 176. As citações seguintes referem-se a este volume das Obras Completas de O. Martins.

(23) Ibidem, p. 193.

(24) "Para bem ver as coisas, é mister colocar-se fora delas: para poder saber-se alguma coisa da sociedade, é mister viver no isolamento": "Os poetas da Escola Nova" (1875), ibidem, p. 156. 
A esta visão selectiva da literatura acrescenta Martins, num texto posterior, a sua teoria antropológica das idades do espírito, em geral partilhada pelos positivistas, segundo a qual a poesia épica sucede civilizacionalmente à poesia lírica (da mesma maneira que aos 20 anos se canta o amor e aos 40 a pátria), vindo a culminar na poesia metafísica ${ }^{(25)}$; a arte superior, viril, encontrar-se-á sempre, portanto, na poesia de contorno histórico ou metafísico, "a grande musa austera" que inspirou, respectivamente, Herculano e Antero. Mas o que então (em 1884) se lhe torna evidente é justamente o declínio da grande arte, em favor da poesia intimista e da prosa dura. O fenómeno sugere-lhe explicações de índole sociocultural: a poesia morre porque falham os sentimentos morais colectivos; porque o egoísmo dos tempos presentes não encoraja ideais nem crenças; porque o desejo de ensinar as plebes apenas as perverte $e$ embrutece, em lugar de as libertar. Rendido aos factos, resta-lhe aceitar a contingência de que a poesia pessoal seja "a única verdadeira".

E não estaria a poesia condenada, como previra Hegel, numa época de raciocínio crítico que naturalmente se exprime em prosa? ${ }^{(26)}$ Não estaria toda a literatura condenada a transformar-se numa distracção amável? Martins não era o único da sua geração a pensar assim. Aliás, duas das principais referências da época positivista, $\mathrm{H}$. Spencer e A. Comte, tinham claramente atribuído às artes um papel subalterno na hierarquia dos bens espirituais: para o autor do Système de Philosophie Positive, elas servem para "charmer et améliorer l'humanité"; Spencer concede-lhes, em On Education, o $5^{\circ} \mathrm{e}$ último lugar na escala da formação útil - o lugar do ócio. Entre nós não faltaram vozes proféticas a anunciar o fim da "alta" literatura, em particular da poesia, embora variem as razões

(25) "Cantar aos vinte anos a mulher que se adora, aos quarenta a pátria que se ama, aos cinquenta, no declinar da vida, o céu que nos espera, ou o desespero que nos rói, ou a dúvida que nos assalta, ou o aniquilamento que pressentimos - eis aí a norma, eis o que é natural e humano. Abundam, porém, hoje em dia vates que antes do buço lhes rebentar experimentam já todas todas as emoções [...]. A poesia ofendida vinga-se geralmente deles fazendo-os nomear amanuenses pelo governo", in "Odes e Canções de Luís Magalhães", ibidem, pp. 34-55.

(26) "Eu adopto até certo ponto a doutrina de Hegel na sua estética. A poesia mirra-se, por isso mesmo que cada dia mais nós pensamos em prosa. [...] Quando o espírito, amadurecendo, reflecte, analisa e critica, não pode mais criar: apenas disseca", in "Três poetas" (1882), ibidem, p. 203. 
invocadas. Bastará lembrar o testemunho expressivo de Antero, em 1881, acerca do "divórcio" entre os poetas e o mundo:

"A poesia deixou de ter missão social. Os raros poetas, que ainda existem, são apenas os restos destroçados duma raça de outras idades e que breve terá desaparecido. A poesia passou decididamente à categoria de literatura amena - ao lado da teologia, outra espécie também de literatura, com a diferença de ser mais enfadonha. Requiescant in pace"(27).

3. Estaria a literatura em prosa, nomeadamente os géneros narrativos, vocacionada para preencher o esvaziamento ideológico da poesia? A verdade é que a própria ideia de sacerdócio das letras que ainda mobiliza grande parte dos escritores desta época seria obrigada a reconverter-se, não apenas nos conteúdos, mas na própria forma de intervenção; para ter alguma influência, a escrita precisava de ir ao encontro do público, no livro e no jornal, moldando-se às exigências de um campo literário já em grande medida profissionalizado, concorrencial e pouco propício a individualismos arrebatados. A opção pelo romance e a sua consagração como o grande género moderno responde em parte a este desiderato: por um lado é a forma mais apta a representar a vida e os problemas do homem comum, o seu público real; por outro lado consente a determinação moralista e ideológica, sem deixar de abrir espaço à sua questionação, encenando os "mundos possíveis" da liberdade humana.

Ora o apogeu do romance, no período realista e naturalista, coincide entre nós com a difusão do ideário republicano e com a influência (por via francesa) das doutrinas positivistas. A adesão da intelligentsia nacional a este duplo formato ideológico constituiu um factor muito importante para o reinvestimento temporário da actividade literária: para o romancista, que aí encontra um novo espaço de proselitismo militante; e para a sua escrita, que assim se reveste de uma dignidade poucas vezes concedida à forma romanesca. Na esteira de Eça de Queirós, um conjunto de autores menores ${ }^{(28)}$ polariza as atenções da crítica, quer na imprensa diária (fazendo concorrência às novidades teatrais) quer nas revistas de índole cultural.

(27) Antero de Quental, "A poesia na actualidade", in Prosas II, Coimbra, Imprensa da Universidade, 1926, pp. 321-322.

(28) É o caso de Júlio Lourenço Pinto, Abel Botelho, Teixeira de Queirós, José Augusto Vieira e Artur Lobo de Ávila, entre outros. 
Sob o influxo do positivismo, a literatura prosística será simultaneamente iconoclasta e de forte pendor pedagógico. Uma das razões do seu sucesso encontra-se por certo na ousadia com que afrontou os poderes dominantes, designadamente a Igreja e a classe política. O sentimento anti-clerical e a simpatia pela ideia republicana estão na origem de uma vasta série de narrativas cujo denominador comum é a representação satírica ou catastrofista das classes dirigentes do País. Paralelamente, deseja-se que a literatura contribua activamente, a par da filosofia e da ciência positivas, para a tarefa pedagógica de regeneração moral. Colocando-se à margem (e acima) dos poderes políticos e económicos, os romancistas fazem-se sociólogos ou proclamam-se cientistas do mundo moral. Ocupar-se-ão preferencialmente da burguesia urbana, a que melhor conhecem e a que mais lhes interessa dirigir; representam-lhe os hábitos de vida, os desejos de promoção e os vícios privados. Se por um lado expõem os segredos da intimidade, por outro vigiam os costumes, com recurso a uma ideologia científica assaz moralista e conservadora. Assim fidelizam o seu público, entretendo-o e endoutrinando-o.

Do ponto de vista simbólico, a aliança entre a literatura realista e a ciência (mediada pelo factor ideológico) representou, deve dizer-se, um ganho funcional imediato: traduziu-se num alargamento da sua influência na esfera pública, num momento em que a instituição literária corria o risco de se fechar em si mesma ${ }^{(29)}$. Todavia, poucos escritores se aperceberam de que, ao rivalizarem com a emergente ciência social, também subalternizavam a sua própria posição, já de certo modo fragilizada pela marginalização da poesia.

Reunir prestígio intelectual e sucesso literário não era porém tarefa fácil, mesmo para os prosadores. Acrescentar-lhe sucesso comercial constituía um feito raro, mas só por si um indicador ambivalente, sem o paralelo reconhecimento da crítica e dos seus pares (tal como hoje, a originalidade considerava-se já um valor simbólico importante no interior do campo literário). Camilo Castelo Branco representaria um desses exemplos raros, se não fosse romântico e ainda sobre isso acusado de ceder à voragem consumista do público. Eça de Queirós nunca conseguiu viver da escrita, mas em contrapartida desfrutava de sólida reputação enquanto romancista de ideias. A maioria contentou-se com

${ }^{(29)}$ Cf. Jacques Dubois, L'Institution de la Littérature, Bruxelas, Nathan-Labor, 1986, cap. III. 
uma situação de meio-termo, ora exercendo outras profissões, ora sobrevivendo entre a actividade literária e a jornalística ${ }^{(30)}$.

$\mathrm{O}$ caso de Fialho de Almeida ilustra bem os dilemas de um escritor dividido "entre o sacerdócio e o mercado" (título de um recente trabalho de Maria Manuela Almeida(31) $)$, que procura encontrar no jornalismo uma alternativa possível às suas frustradas ambições. Inconformado com a situação de dependência económica, o autor de $O$ País das Uvas não se cansa de denunciar as perversões do meio literário nacional que obrigam os jovens talentos a tornarem-se polígrafos ou funcionários, sob pena de descaírem na "obra de fancaria" para sobreviver. O principal problema reside, segundo ele, na fraca dimensão do mercado livreiro que coloca o escritor à mercê dos editores ${ }^{(32)}$.

No texto sobre Coelho Neto já atrás citado, enumeram-se outras causas pelas quais a literatura não tem em Portugal valor negociável: o analfabetismo da população, a escassez de bibliotecas, a falta de leitores e de críticos, em suma, a inexistência de uma atmosfera intelectual que sirva de estímulo à produção. Acima de tudo Fialho lamenta "a completa ausência do elemento intelectual nos cargos dirigentes", do rei ao governo e à sua coorte de bacharéis, para quem a cultura constitui uma ameaça aos privilégios; o exemplo de outros países, cujos governantes acarinham os seus homens de letras, oferecendo-lhes cargos dignos, não poderiam

${ }^{(30)}$ A literatura realista, na esteira de Illusions Perdues, de Balzac, também nos oferece algumas representações ficcionais do mesmo conflito nos jovens aspirantes a um lugar nas Letras que as contingências do meio condenaram ao silêncio, à loucura, ou simplesmente ao abdicar das ambições - veja-se A Capital!, de Eça, ou A tragédia dum homem de génio obscuro, de Fialho; de certa maneira são a contraface moderna e desencantada dos Alencares.

${ }^{(31)}$ Maria Manuela Almeida, A Literatura entre o Sacerdócio e o Mercado. Balzac e Fialho de Almeida, Braga, Angelus Novus, 1996.

${ }^{(32)}$ Fialho de Almeida, "Alguns livros", in Pasquinadas. Jornal dum vagabundo, Porto, Livr. Chardron de Lello \& Irmão, $4^{\text {a }}$ ed., s.d., pp. 231-233 (textos de 1889). Segundo as contas de Fialho, o autor de um livro novo aufere em média um prémio de 200 a 300 mil réis por uma edição de 1500 exemplares; destes apenas 900 se vendem ao fim dum ano, o que, a crer nos editores, apenas cobre os custos de impressão. No texto sobre Coelho Neto estas cifras confirmam-se na generalidade, sendo aduzidos elementos de comparação com os escritores de maior público, como Camilo, Eça e Pinheiro Chagas. Também Ramalho Ortigão apresenta dados interessantes acerca da indústria intelectual, a propósito dum novo imposto sobre os rendimentos da escrita, R. Ortigão, As Farpas, vol. II (epístola n ${ }^{\circ} 7$ ). 
vingar entre nós. Mas também aos escritores atribui responsabilidades pelo ostracismo, nomeadamente a falta de energia criativa, a desnacionalização, a "desestima" por si próprios e, por consequência, "o seu pouco valor proselitista". Além de disciplina e profissionalismo, os escritores carecem de reforço crítico, ou seja, da "[...] conviç̧ão formal do papel alto que exerce quem paira acima duma grande élite social, subministrando-lhe ideias ou planos de conduta, interferindo-lhe nos destinos, guiando-a d'alto, no meio dos respeitos duma turba convicta, única que marcha..."(33).

Dinheiro, independência intelectual e consciência da sua vocação dirigente: três condições que a literatura necessita para aliar ao valor negociável a recuperação do valor simbólico. Pese embora a sua posição algo marginal e bastante ressentida, Fialho tem o mérito de levantar com raro desassombro questões que preocupavam os seus contemporâneos. Chamando a atenção para o problema económico ou para o problema simbólico, muitos intelectuais constatam, com diferentes tipos de reacção, a perda de reconhecimento social das Letras e da literatura em particular ${ }^{(34)}$.

Do lado dos escritores que desfrutam de maior popularidade, como era o caso do círculo anteriano (os chamados "vencidos"), a atitude dominante parece ser de resignado conformismo, de que já vimos exemplos. Todo o percurso desta geração se pautou pela defesa da autonomia do campo intelectual face aos poderes, o que não contradiz o pressuposto da supremacia intelectiva na esfera político-social. O ideal da independência e da meritocracia foi a bandeira sempre empunhada pelo grupo de 70 para legitimar a sua posição no espaço público e no meio literário (recordem-se as intervenções contra Castilho e contra a Academia) ${ }^{(35)}$.

(33) Barbear, Pentear, ed. cit., p. 145.

${ }^{(34)}$ A Medicina e a Antropologia positivistas também contribuíram, com as suas doutrinas sobre o génio como degenerado superior, para desqualificar a imagem simbólica do grande escritor (vejam-se as Nosografias de Antero e Camilo). Na Nosografia de Camilo Castelo Branco, de Alberto Pimentel Filho (Tese Inaugural, Porto, Imprensa Portuguesa, 1898) lêem-se estas palavras reveladoras: "O valor deste homem consistiu em escrever romances. A muitos há-de parecer futilidade isto; escrever romances!? Triste mister, para o qual não é necessário grande afinamento científico. Concordo com isso, plenamente. De resto, os pobres literatos são quase sempre figuras doentes, arrastados a esse vício de escrever pela própria doença. E em Portugal a palavra literato é pouco menos de sinónimo de pobretão e vadio" (p. 85).

(35) Abordámos esta problemática num artigo intitulado "Geração de 70: a construção interna da memória", Vária Escrita, n 4, 1997, pp. 31-43. 
Ramalho Ortigão, o publicista do grupo, encarregou-se de salientar, nos momentos laudatórios oportunos, a diferença que representa este novo conjunto de intelectuais, que não depende de nenhuma instituição de poder, não recebe benefícios do Estado e não reconhece outra autoridade a não ser o aplauso do público e dos seus pares. Mas é o mesmo Ramalho quem observa, em momentos de assinalável lucidez, as consequências a retirar da autonomia, a saber: (i) que manejar ideias e manejar homens são tarefas distintas e até certo ponto incompatíveis; (ii) que os artistas não são filósofos nem sociólogos mas antes "criadores de realidades", aí residindo a sua grandeza e também a sua inferioridade ${ }^{(36)}$.

$\mathrm{Na}$ hora de traçar o balanço do seu trajecto combativo, a maioria destes intelectuais enfrenta a erosão do seu magistério pelo afastamento em relação às "turbas ignaras", o que lhes permite sublimar a sua actividade através de um discurso parcialmente conformista. Parece-nos ser esta a atitude de Eça de Queirós, no ponto de viragem da sua evolução literária, no final dos anos 80 . A percepção do fenómeno de industrialização e massificação da literatura leva-o a reavaliar o papel social do escritor numa época que alterou - para bem e para mal - a relação comunicativa com o seu público. Esse processo de transformação vem magistralmente descrito no prefácio de Azulejos, do Conde de Arnoso, em $1886^{(37)}$. O escritor é agora o "humilde fazedor de livros", justamente quando o livro se faz "coisa viva", mas também um produto que se consome, ao ritmo do mercado e das máquinas rotativas:

"Essa coisa tão maravilhosa, de um mecanismo tão delicado, desapareceu; e começaram a mover-se as multidões, governadas por um instinto, por um interesse ou por um entusiasmo. Foi então que se sumiu o leitor, o antigo leitor, discípulo e confidente [...]: e em lugar dele o homem de letras viu diante de si a turba que se chama o público, que lê alto e à pressa no rumor das ruas" ${ }^{\prime \prime(38)}$.

Paradoxalmente (ou talvez não), Eça defende no mesmo texto a transcendência da Literatura, não enquanto mobilizadora de acção mas

(36) Cf. Ramalho Ortigão, As Farpas, vol. II, Livr. Clássica Editora, s.d., p. 291.

(37) Eça de Queirós, "Prefácio dos Azulejos do Conde de Arnoso", in Notas Contemporâneas, Obras de Eça de Queiroz, vol. 2, Porto, Lello \& Irmão, s.d., pp. 1431-1443.

(38) Ibidem, p. 1433. 
pelo seu poder de produzir memória, "essa eternidade relativa que só dá a Arte". Ao mesmo tempo contrapõe-lhe a glória efémera da política, condenada à voragem do tempo. Esta exaltação da literatura suscitou várias reacções, entre as quais uma vigorosa réplica de Oliveira Martins. Trata-se de um conhecido artigo, intitulado "Pró Política"(39), onde o autor de Portugal Contemporâneo denuncia a situação confortável e algo frívola dos artistas: "A questão é que vocês, os literatos, têm o beau rôle; porque apenas produzem palavras, enquanto por cá é necessário fazer mais alguma coisa, fazer actos, res, non verba". Lembrando ao amigo que a imortalidade é um mito romântico, Martins faz-lhe ver que nas democracias tudo se consome no anonimato colectivo, como nos tempos primitivos.

Neste ponto estava Eça intimamente de acordo: também ele suspeita que o destino do "fazedor de livros" possa estar sujeito ao processo irreversível do industrialismo literário, que rarefaz e desindividualiza a palavra. O drama do escritor moderno no final do século será precisamente o do seu ambíguo estatuto numa sociedade que deixa de o ver como mentor; numa cultura que começa a desviar-se da sua matriz literária e apenas espera da arte uma fruição íntima ou um entretenimento inofensivo. Isso mesmo constatará Max Weber ${ }^{(40)}$, poucos anos mais tarde:

"Não é por casualidade que a nossa arte mais elevada seja hoje uma arte íntima e nada monumental, nem que apenas dentro dos mais reduzidos círculos comunitários, na relação homem a homem, em pianíssimo, sopre essa força que corresponde ao que noutro tempo, com pneuma profético, em forma de fogos tempestuosos, atravessava, fundindo-as, as grandes comunidades".

Cada um a seu modo, os testemunhos de Oliveira Martins, Antero, Eça e Fialho traduzem a falência de um ideal herdado do Romantismo: a crença na Literatura como poder espiritual das sociedades modernas. Desfeita a ilusão, resta-lhes cultivar o isolamento ou aceitar os factos. Afinal, o sacerdócio da escrita é já um anacronismo que só pode representar-se conscientemente sob o signo da nostalgia.

(39) Oliveira Martins, "Pró Política", in Dispersos, vol. II, Lisboa, Oficinas Gráficas da Biblioteca Nacional, 1924, pp. 106-112.

${ }^{(40)}$ Max Weber, O Político e o Cientista, trad. de Carlos Grifo, Lisboa, Presença, 1973, p. 187. 